\title{
Robert Adams in Transatlantic Review: Archiving the Barbary Captive and Traveller
}

\section{Stephen F. Wolfe}

\section{(2) OpenEdition \\ Journals}

Édition électronique

URL : https://journals.openedition.org/ejas/9873

DOI : 10.4000/ejas.9873

ISSN : 1991-9336

Éditeur

European Association for American Studies

Référence électronique

Stephen F. Wolfe, «Robert Adams in Transatlantic Review: Archiving the Barbary Captive and Traveller », European journal of American studies [En ligne], 7-1 | 2012, mis en ligne le 06 décembre 2012,

consulté le 08 juillet 2021. URL : http://journals.openedition.org/ejas/9873 ; DOI : https://doi.org/ 10.4000/ejas.9873

Ce document a été généré automatiquement le 8 juillet 2021.

Creative Commons License 


\title{
Robert Adams in Transatlantic Review: Archiving the Barbary Captive and Traveller
}

\author{
Stephen F. Wolfe
}

\begin{abstract}
"Travelling is always a travelling in traces, is always the pursuit of traces to be followed and read, and that the reading of these traces is more of an adventure than travelling itself" (Pfister,
\end{abstract}

1 In 1817, in the May and July issues of the North American Review, Jared Sparks set out to challenge the veracity of The Narrative of Robert Adams, an American sailor who was wrecked on the western coast of Africa, whose story had been published in London in 1816. At this time Jared Sparks was acting editor of the North American Review and seeking to make a name for himself in American letters. Sparks had been born in Willington, Connecticut, in 1789, studied in public schools, worked for a time as a carpenter, and then became a schoolteacher. In 1809-1811 he attended Phillips Exeter Academy and graduated from Harvard University (A.B. 1815 and A.M. 1818). He had studied theology at Harvard and was college tutor in mathematics and natural philosophy from 1817 to 1819. In contrast, Robert Adams, first known as Benjamin Rose, was an American sailor found destitute on the streets of London in 1815. He had a fascinating story to tell: he had been shipwrecked off the Northwest Coast of Africa, taken captive and enslaved more than once. He had crossed the Sahara, spent six months in captivity in Timbuctoo, and was later ransomed by the British consul. He returned to America via Cadiz and London, where he presented himself as a Barbary Coast Captive and a Christian slave, and the first "Christian" man to have lived in Timbuctoo for generations.

2 These two men's trajectories could not have been more different: Sparks would become President of Harvard and one of the most important early American historians, while Adams would sail away from the city of London, disappearing without a trace, but the Narrative of Robert Adams would be published on both sides of the Atlantic and in 
Europe, over the next 20 years creating controversy throughout its publication history (C. H. Adams, A Critical Edition, lvii). I want to examine constructions of this text by its two London editors and then its reconstructions by various reviewers as it criss-crossed the Atlantic. By reading the narrative transatlantically, we can examine its role in public debates about exploration, Timbuctoo, trade routes in Northern Africa, race, and authorship in the first decades of the $19^{\text {th }}$ century. The text also gives us an indication of the ways in which people and texts circulated within the transatlantic region. The narrative, wherever and whenever it came to rest, located "Robert Adams" within sets of conflicting discourses and medial representations: Adams could be a trustworthy narrator within the discourses of travel and empirical authentication, or a fraudulent figure with a story to sell within the well-known Barbary Coast captivity narrative, or perhaps both?

3 Adams was an American sailor who was "found" by Simon Cock, one of the text's editors, wandering the streets of London in 1815. His story of shipwreck, captivity, enslavement, brutal treatment, and attempts to convert him to Islam seemed an excellent opportunity for the Committee of Merchant Traders to Africa to make a contribution to the popular Barbary Coast captivity narrative. ${ }^{1}$ The figure of Adams is shadowy from the first: he is described as a destitute beggar (9), and a man not "fair" skinned, perhaps black. ${ }^{2}$

4 Additionally he is an unwilling narrator whose memory is not always clear. Therefore, his two amanuenses have, at different times, to verify the details of his wanderings in the desert and his visit to Timbuctoo through detailed questioning and a long pedagogical format. The two editors' commentaries emphasize accumulative details and geographical accuracy in their reconstruction of Adams' story. The first editor is Mr. Joseph Dupuis, the British Vice-Consul in Morocco who paid Adams' ransom and put him on a boat, first to Cadiz and then to London in 1814. The second editor is Simon Cock, who worked for the Company of Merchants Trading to Africa. Dupuis provides many of the Notes for the 1816 text, verifying descriptions of places, people, and ethnographic practices, based upon his own personal experience in Africa. Simon Cock is the framing "as told to narrator" of The Narrative of Robert Adams; he had published previous pamphlets defending free trade, including the slave trade, and had worked with various shipping companies in Liverpool and London on behalf of companies participating in the "triangular trade" with Africa. It is Cock who writes the first draft of Adams' "narrative" and sets up the initial set of interviews with "gentlemen who interest themselves in African affairs," "scientists," and members of the Admiralty and the government (13). He was also responsible for editing the entire volume for publication. ${ }^{3}$

5 Additionally, Adams was not able to narrate a "continuous and strait-forward story" (11) but only to answer questions put to him, first by Dupuis in 1810 in Africa, and then in 1815-16 in London. The editors had to construct Adams' "story" from fragments. Thus, Cock felt the need to bring in a group of "scientific and respectable gentleman" to interview Adams, seeking verification of details and geographical descriptions of Africa. This highly mediated captivity narrative is presented in the form of gathered information, focusing on Adams' journey and stay in Timbuctoo. 
6 In fact, the geographical information in the text is continually compared with that supplied in Mungo Park's text (see footnote 1) (11, 68-97, 127-135). The map at the beginning of the Adams text is the same map as in the Park text, drawn by Major James Rennell, a respected geographer. The map is supplementary, in Jacques Derrida's sense, in that it both adds to and substitutes for the written text (144-45), tracing the moving subject of the travel narrative onto a static map. Additionally, the commentary, notes, and appendix that frame the four-chapter Robert Adams narrative suggestively trace the figure of Park just below the surface of Adams' text, just as Adams' route or movements are traced on the fixed form of the Park map. Printing choices seem to confirm this - in the words of a contemporary English review by John Barrow, the Adams text is "on a footing with the two volumes of Park: it is accordingly printed in a uniform manner with those volumes" (Quarterly Review, Jan. 1816 473). ${ }^{4}$ John Murray was the publisher for the Admiralty and of the Quarterly Review.

7 The palimpsestic character of the book, with its use of Rennell's map and elaborate editorial details, added to its reliability for the audience but also put the two texts "on an equal footing"; both formed part of an "archive" in which the writing up of the "story" stabilizes the narrator, his observations and his actions within a reified text. In the London text, authentication is more important than storytelling: the objective seems to be to locate a subject and his narrative within discourses that will lend credibility to the subject himself and to the editors. Through the accumulation of details, consistency had to be established within disciplinary frameworks such as natural history, ethnographic reportage, and previous historical and geographic knowledge as recorded in other texts. The object of this sort of rhetorical formation, is to make this performative narrative of a dislocated sailor into a didactic text by creating a privileged space of enunciation before a group of examiners (Wilson 49). Bruno Latour argues that a knowledge of places and peoples "at a distance" relied on assemblages of evidence such as maps, measurements of distance and time, journals, and specimens gathered together in metropolitan "centres of calculation" (Latour 220). These urban clearing houses of data, such as Kew Gardens, the British Museum, the Royal Geographical Society, and the other societies for geographical exploration founded during the late $17^{\text {th }}$ and throughout the $18^{\text {th }}$ centuries were places to catalogue and stabilize the "immutable mobiles" of travel for the purpose of comparison and the "accurate representation" of distant places for the purposes of scientific study (Latour 215-250)

8 The two editors set up an over-determining discourse that is constantly mediating between Adams' travels and his ability to communicate. Since Adams cannot read or write, it is a construction and verification of his "evidence" as well as of his spoken words for the reader. At certain points in the text, both editors' notes on the same passage offer an embedded double commentary, setting text inside texts (79-80). This is complicated by Cock's choice of a third-person narrative "voice" in the four-chapter Adams narrative section of the book (26-67). In contrast to the Adams narrative, in "Introductory Details Respecting Robert Adams" (8-19) by Cock and in Dupuis's "Notes and Illustrations of Adams Narrative" (68-105) each editor speaks in the first person. Adams' own words are framed within comments and questions in the editors' "own words". The four-chapter Adams narrative is presented within the editors' five-part structure of authentication: an introductory chapter by Cock; the map and its "Advertisement" by Rennell; the notes and illustrations at the end of the text by 
Dupuis; and two additional appendices, one by an unnamed member of the African Committee and another by Dupuis.

9 In The Unvarnished Truth, Personal Narrative in Nineteenth Century America, Ann Fabian argues that "extensive appendices were common in African travel narratives, particularly when explorers claimed credit for significant discoveries, but the appendices in Adams's book were designed as much to prove the man a plausible narrator as to document his discoveries" (29). The editors create a set of framing discourses and notes, or in Michael de Certeau's useful phrase, "referential testimonies" (31) - texts and people that establish "common opinion," providing accepted facts about the geography, customs, and ethnography of Northwest Africa. Also, it is interesting to note that the actual details of Adams' shipwreck, capture, suffering, wanderings in the desert, and eventual ransom do not play as important a part in this narrative as in other Barbary Coast narratives of the same period published in Britain and America. ${ }^{5}$

10 The book begins with a process of negotiation involving a continual exchange of discursive performances in which the created speaker/author Robert Adams, his editors, and his questioners produce "a mutual and mutable" recognition within representational discourses. The terms of cultural engagement "whether antagonistic or affiliative, are produced performatively" at the beginning of the text (Bhabha 5). It is both a place of encounter and a site of the attempted authentication of difference in which "anxieties of authenticity" (Burnham 172) are acted out. There is a consistent tension between Robert Adams, a Barbary captive and a ransomed sailor, and Adams the undefined "other" of mixed race and uncertain origin but with "scientific and documentary" evidence that is of interest to his audience. By setting out to prove the reliability of the narrator and his geographic and chronological memory, the editors, Cock and Dupuis, demonstrate a set of strategies or "styles" that both reveal and disguise Adams' identity.

11 Additionally, the staging of Adams' performance takes place on a set of medial borders. I have used the word "staging" with some care, in that the narrative does not begin with "the Adams narrative" but with questions about previous sightings of the ransomed sailor in Africa, Cadiz, and then in London. In other places in the text, Adams dissolves into the shipwrecked sailor Benjamin Rose, who journeyed to Timbuctoo $(17,70,106)$ and was ransomed. The text's opening section also constitutes a continual process of finding and reorienting Adams within his own story and to the needs of his auditors. One detail is quite important here: Adams, if he was a sailor, would have been literate, since "seamen were substantially literate" during this period (Blum 144-6). The text demonstrates the ways in which the two editors negotiate between their presentation of Adams' story and the possible representations of evidence and authentication that must accompany his narrative of enslavement, his knowledge of geography, exploration, and history. For example, Adams' knowledge of distance and direction is based on the following commonplace analogy: "Being a sailor, he observed, he had the habit of noticing the course he was steering at sea; and therefore found no difficulty in doing so, when traversing the Deserts of Africa, which looked like the sea in a calm" (Adams 12). The negotiation takes place within a discursive contact zone, in which the narrators are testing Adams "stylistic indices" to see which will best reveal the accuracy of "speaker's" words within the available discourses of his "collaborative" editors and interrogators. 
12 What is odd, and what both Dupuis and Cock admit is problematic, is not how to represent "Robert Adams" within an "orientalist" archive but how to account for Adams' inconsistencies of appearance and behaviour-the man has been "seen" a number of times between 1810 and 1815, but he seems to float away from affiliation with any community and he moves between racial categories and linguistic markers. Adams has told Cock that he wants only to return to the Hudson Valley in New York, yet he does seem to realize that his narrative would be of interest to an "audience of scientific and commercial" gentlemen in London and is willing to stay to satisfy their thirst for details "too curious to be suppressed" (Adams 14). Cock informs the readers that Adams appears and reappears in London from his first sighting in October 1815 to the publication of the text in 1816. And then later in 1816, Adams disappears again, not staying to collect his promised royalties, nor is there any record of him returning to New York State (xvi-ii, 162-182).

II

13 As suggested above, Adams' alterity becomes more and more complicated as the narrative develops. In his opening "Introductory Details Respecting Robert Adams," relating his first encounter with Adams in Africa in 1810, Dupuis describes him as having the appearance, features and dress perfectly resembling those of "an Arab" and speaking a mixture of Arabic and broken English.

The appearance, features and dress of this man upon his arrival at Mogador, so perfectly resembled those of an Arab, or rather of a Shilluh, his head being shaved, and his beard scanty and black, that I had difficulty at first in believing him to be a Christian. When I spoke to him in English, he answered me in a mixture of Arabic and broken English, and sometimes in Arabic only. At this early period I could not help remarking that his pronunciation of Arabic resembled that of a Negro, but concluded that it was occasioned by his intercourse with Negro slaves.

Like most other Christians after a long captivity and severe treatment among the Arabs, he appeared upon his first arrival exceedingly stupid and insensible; and he scarcely spoke to any one. (15)

Paul Baepler argues that this comment displays "a fear that the boundary of identity is closely linked to language and that language acquisition - particularly under the duress of captivity - comes perilously close to cultural assimilation" (1999 42). But it also introduces the uncertain ways the narrator's race is presented in the text. Adams' "appearance, features and dress ... so perfectly resembled those of an Arab, or rather of a Shilluh, ... that [Dupuis] has difficulty at first believing him to be Christian," and he is mistaken for a Moor. Also, early in the text, Dupuis accounts for Adams' "colour" by a reference to his complex family history: "he was born up river of New York, where his father lived," while "his mother was a Mulatto, which circumstance his features and complexion seem to confirm" (17). In an aside, one editor states that Adams is a "very dark man, with short curly black hair" (47) while his Arab captors single him out as white $(55,60)$, and both editors assert that he is the first "white man" to visit Timbuctoo. Later in the text there is an imbrication of ethnicity and language when Dupuis asserts that Adams' "pronunciation of Arabic was at all times indistinct, and often quite incorrect" (75), but that Adams "did know something of the Negro language" of Africa (91).

15 The editors create a lone, multilingual sailor who might pass unnoticed in foreign lands, yet they are not quite comfortable with such a construction. Adams is clearly not 
the man of moral courage, self-sacrifice, and immediately recognizable authority that the editors sought and that later generations of commentators on African exploration would venerate. They seem aware of this by drawing attention to Adams' moral choices: he did not convert to Islam, nor was he "cowardly"; instead he offered resistance to the demands of his African captors (55-56, 61-63).

16 But his appearance to Africans is also significantly variable. Dupuis asserts that the African tribes who had held Adams captive "had never seen a white man before". Adams's alterity is framed in categorical terms: for example, Dupuis notes that "I do not imagine that the curiosity of the Negroes can have been excited so much on account of Adams's colour, as because he was a Christian, and a Christian slave, which would naturally be to them a source of great astonishment" (89). In fact, he is called by one group of his captors in Africa "a Christian who never prayed" (57). "Christian" was a coded word for "white" in the Barbary Coast captivity narratives, novels, and plays published between the $16^{\text {th }}$ and the $19^{\text {th }}$ centuries. The consul asserts that the Negroes of Africa must have seen, in caravans from the Barbary states, many Moors of a "complexion quite as light as that of Adams" (89). Thus it has been assumed that Adams is racially Creole or "mulatto" (ix, 89, Baepler 1995 25).

17 While the stress is on Adams' shifting identity, the ways in which his editors have created Adams' silences are even more problematic: both fascinating and frustrating (98-99 for a return to the scene above, but with a slightly different commentary by Dupuis). As suggested above, the editors say that "the narrative was drawn from Adams, not as a continuous and strait-forward story, but in answer to the detached, and often unconnected, questions of the Editor, or of any gentlemen who happened to be present at his examinations " (11). There is, in the words of critic David Johnston, “ the rigorous impossibility of deciding who or what Adams might have been-outside, perhaps, his status as a curiosity, which is well documented" (363).

18 In fact, the role of "curiosity" and the aesthetics of curiosity in the literature and intellectual history of the late $17^{\text {th }}$ through early $19^{\text {th }}$ century in England are complex. In her fine study Curiosity, A Cultural History of Early Modern Inquiry, Barbara M. Benedict has demonstrated that "the question confronting spectators and readers of curious explorations and experiments was whether to believe the writer" and travellers had long aroused suspicion because homebound readers could not verify their tales. Writers during the period deliberately invited the reader's scepticism as a way of verifying their own credibility (28). The editors seek to transform the narrator's "eager and systematic curiosity" (Adams 80 ) into a scientific empirical narrative.

19 For Cock, Adams has to be provided with a personal history and narrative credibility so that his descriptions can be collected and accumulated "systematically" into a stable archive of material. Both editors sought to authenticate the man who was captured, sold into slavery, and ransomed under the name of Benjamin Rose in 1810. They do this in their introductory chapter by close questioning, having him chart his routes on existing maps, providing details of the physical features of the Moorish and Negro tribes, and then providing detailed descriptions of his travels to Timbuctoo, Wed-Noon, El Kabla.

20 The editors also argue repeatedly that Adams is an artless narrator who speaks "with utmost simplicity" in a language which has the "internal marks of truth" $(16,111)$. He has resisted the "temptation (no slight one for an ignorant sailor) of exciting the wonder of the credulous, or the sympathy of the compassionate, by filling his story 
with miraculous adventures, or overcharged pictures of suffering" (111). Adams "is rather subordinate to the circumstances of his story, than himself the prominent feature of it; and almost every part of his Narrative is strictly in nature, and unpretending" (111): he is "too ignorant to invent himself" (109).

21 As indicated above, Simon Cock finds it necessary to introduce a set of socially and scientifically qualified members of the African Association, the Royal Society, and Parliament to interrogate and inspect Adams. Dupuis writes that he did the same sort of thing five years before to establish the credibility of Adams, except that he then enlisted the aid of nomadic traders who had been to Timbuctoo. Additionally, the process requires that the editors collate existing written texts with Adams' observations. They place his travel narrative within an existing archive of travel journals, maps, and earlier plans to seek the source of the Niger River and the search for Timbuctoo. Their chief points of comparison are the previously published expeditions of Mungo Park, which comprise most of the "Notes and Illustrations" section of Adams' narrative. These editors are listening to Adams while reading Mungo Park (71-2). But most importantly, other narratives, maps, and geographic and ethnological readings can be located "on the existing network so that a representation of the distant world can be constructed in the metropolis" (Leask 21).

The narrative begins with a description of a found narrator - a beggar and a seaman. $\mathrm{He}$ is, as the editors agree, a "curious character" - the secretive and marginal other who violates racial and social categories. He is most importantly a sailor: a figure of inter- and transnational movement who participated in the shifting production and exchange of labour during this period (Linebaugh 402-450, Blum 138-142) and whose disturbing hybridity haunts the text. In the first two sections of this paper it has been argued that the editors use such a figure to intervene in a public debate at the end of the Napoleonic Wars between the interests of "scientific exploration," international trade and commercial development in Northeast Africa. On the other side of the Atlantic, the Adams text was an indication of how credulous English "gentleman of science and commerce" could be when their own interests were served by "creditable testimony" (Barrow 472). The popularity of the text was an example of "unregulated curiosity"(472) masking the ambitious self-interest of the Company of Merchant Traders to Africa and The African Association. And by May 1817 another narrative by Adams had come to light, which Jared Sparks was to publish in the North American Review.

III

23 Jared Sparks was at this point the acting editor of the North American Review, and in May and July of 1817 he devoted two articles to Adams: the first is an earlier version of the Adams narrative "collected from Adams in Cadiz, ... before he went to London" (147), and the other his critical review of the London edition of the Adams text of 1816 . Sparks states, in his short introduction to the first version of Adams' narrative, that the original version of the narrative had been "withheld from the publick, because the writer ... found reasons for suspecting the veracity of Adams, particularly in regard to what he says about Tombuctoo, and of his travels among the negroes" (147). The first narrative was taken down from Adams' testimony in Cadiz in 1814 and can be confirmed by Samuel A. Storrow (179-179). But now that the London edition will soon be published in the United States, he wants his readers to have access to both texts and 
for them to understand the reasons that the second narrative has "excited such curiosity... on the other side of the Atlantic" (147).

Sparks frames his assessment of the first narrative within an interesting comment about current interest in Timbuctoo "about which so much has been said and conjectured, and so little is known" (147), and then remarks upon the political, economic, and scientific desire to explore the Maghreb for trade and missionary colonization that developed after the Napoleonic Wars and the Anglo-American War of 1812 to 1815 . He states in May 1817 "our readers will doubtless recollect the notice taken of it in a late number of the Edinburgh, and of the Quarterly Review, and also in several other English publications" (147). Sparks then publishes Adams' first short narrative without commentary. This narrative is written in the first person, and has no footnotes or editorial apparatus. The focus is on personal observations, geographical descriptions, social customs, and the simple naming of plants and animals in quite simple language. Sparks acknowledges that this short text has the authority of a witness and that that Adams may have been captured and transported to Timbuctoo. Living there for nine months, Adams may have had some freedom to move about the city, but he was a slave and, according to Sparks, misread what he saw. The great trading centre of legend described as a centralized state controlled by one "Negro" prince and this is improbable, Sparks suggests.

When later in July, Sparks published his second article, it was a review of the British edition of the Adams' text, published in Boston by Wells and Lilly in 1817. Now Sparks places the text within a different set of contexts. He compares Adams' descriptions of African geography, Timbuctoo, and social customs with known representations from previous historical texts of British, Spanish, Moorish, Muslim, and Turkish origin. He is setting himself against the London editors of Adams' second text demonstrating his own knowledge of exploration texts and classical scholarship. Sparks finds both versions of Adams' text unreliable, containing information that cannot be verified in existing written texts or journals of exploration.

Both Adams texts are "a fiction, and a gross attempt to impose on the credulity of the publick" (162). Jared Sparks looks at measurable differences, temporal dislocations, "verifiable information" available from previous sources about Timbuctoo, and the political and cultural realities surrounding Adams' text. He shows that there is no connection between Adams' descriptions of Timbuctoo and the city as described and recorded in books of history or exploration. He points to the difference between "facts" known about Timbuctoo or the course of the Niger River, and "fictions" created by Adams' editors to meet the needs of their readers. Adams has the talent to disguise both his ethnicity and his own purposes. Both the first and second texts are "an imposture" (181) but more importantly, his English audience were deceiving themselves. Their desire to expand commerce and missionary colonialism in Africa has caused them to embrace the Adams narrative with "unbounded curiosity" (166).

Sparks' use of the discourse of curiosity exposes two different uses of it in the rhetoric of transatlantic evaluations of popular narratives of travel and exploration in the early $19^{\text {th }}$ century. First, there is the ideal of the transparency of difference, a conviction that much could be revealed to the reader and reviewer by clear questions and honest answers - all could be reasonably explained and well-ordered. Foreign differences were subject to "rational articulation," analysis, and negotiation. This clashed with a different mindset that suggested the role of the reader and reviewer was to expose the 
hidden machinations and justifications of individuals and institutions. These narratives are the public expression of how individuals or institutions present their own selfinterested desires through a popular appeal to exotic or singular objects and places (Leask 4, 15-53). Thus, the English editors and reviewers of Adams' text embody unregulated "curiosity" by failing to differentiate and sustain a hierarchy of values (Benedict 233-237), while Sparks can penetrate and demonstrate his own inquisitiveness by exposing the foreign policy interests of the British who wanted to develop commerce and promote missionary work in trans-Saharan Africa.

Another way to examine these responses to the Adams text and the discourse of curiosity is through the interesting argument of Michael Heffernan in his essay "A Dream as Frail as Those of Ancient Time: the In-credible Geographies of Timbuctoo." The article focuses upon texts of exploration and travel in the $18^{\text {th }}$ and early $19^{\text {th }}$ centuries as they depicted Timbuctoo. Timbuctoo became an "idealized mythical site: the byword for unimaginable distance, remoteness, and isolation" and past riches (206). Heffernan shows how Timbuctoo was widely accepted as "the idea of a great desert metropolis, the heart of a vast African trading empire," and that a trans-Saharan trade in gold, spices, and slaves was worth great sums, providing a glimpse "into the possibilities of the penetration of Africa and the continent's unlimited riches" (206). Additionally, a trading system could be established along rivers such as the Niger or the Congo, as cities along these rivers would become "oases of affluence" for whatever European country has managed to establish its credibility and geographic expertise in the exploration of Timbuctoo.

In England, in the first two decades of the $19^{\text {th }}$ century, four texts stood out as focusing on the search for the headwaters of the Niger River and Timbuctoo: Mungo Park's two books, Travels in the Interior Districts of Africa (1799) and A Journal of a Mission to the Interior of Africa in the Year 1805; and James Grey Jackson's two reports in his An Account of the Empire of Marocco, and the District of Suse: compiled from miscellaneous observations made during a long residence in, and various journeys through these countries; to which is added, an accurate and interesting account of Timbuctoo, the great europium of central Africa, published in London in 1809 and in Philadelphia in 1810, and his second volume, An Account of Timbuctoo and Housa, Territories in the Interior of Africa (1820), which was an extensive revision of the first volume. There were also narratives of American shipwrecked sailors who claimed second-hand knowledge of the area, such as James Riley, John Foss, Charles Cochelet, and Judah Paddock. But this is exactly what made Adams' narrative so appealing: he had first-hand knowledge and his narrative did not seek to intervene in debates about Abolition.

Heffernan scrutinizes how geographical information in the period was influenced by a complex rhetoric focused on a moral assessment of the explorer/narrator; particularly the latter's race and his social status. He also argues that an intense battle raged at the beginning of the $19^{\text {th }}$ century between London and Paris to assess the rival claims to knowledge of and authority over North West Africa. There was an attempt to integrate travel and scientific discourses through a careful assessment of the training and character of the explorer. Heffernan uses the Adams narrative as one example of how easy it was to dismiss certain forms of "evidence" collected about a place like Timbuctoo by focusing on the "moral character" of the explorer: Adams was illiterate, he was assumed to be "not white," and therefore he could have no grounding in European geographic knowledge (209). Heffernan discusses in detail a "storm of 
controversy" that erupted around Adams' text in France led by the French reviewer Edme Jomard. Jomard argued that Adams' illiteracy meant that he could not be aware of European geographical knowledge at the time, let alone Arab descriptions of Africa from earlier periods. Also, Adams' "blackness" set him "outside" the Anglo-European scientific models of credibility. Heffernan also argues that the rivalry caused a flagrantly partisan desire in France to belittle achievements verified by "scientific authorities" in England. I am applying this same kind of analysis to American writers after 1814 such as Sparks, while developing the argument in a different direction by focusing on themes of Authority and Curiosity within transatlantic contexts.

While Adams' race was certainly problematic for his French and American audiences, the debate about the text was also a transatlantic one. Adams was a source trusted by the British scientific establishment and by certain British foreign policy interests. However, both France and America had recently fought a war with Britain and wanted to make the Adams narrative a focus for close scrutiny and censure, both concerning African exploration and commercial ambition but also as a test of national character. In literary and popular reviews in both countries the text was not creditable, but the question of who had the right to travel and "explore" with political and moral authority in the Mediterranean was. The issue of what kind of materials and testimony could be brought back from distant lands to enter the archives of organizations such as the British African Association or the records of the Royal Society addressed matters of authority and the contested nature of what comprised legitimate geographical knowledge. Jared Sparks was not the only one to find the narrator "morally inappropriate" in the coded language of the time. As I argued above, the constructions of Adams's alterity made him a changeable presence: sometimes an enslaved Christian sailor (white), sometimes mistaken for a "Negro Tribesmen"; sometimes a beggar on the streets of London claiming "British/American" citizenship; while at other times an American sailor Benjamin Rose travelling under the name of Robert Adams. ${ }^{7}$ He was the flip side of the explorer, who some thought should travel in national uniform, collecting "specimens," making careful "scientific observations," while recording it all in a to-be-published journal or narrative of his travels.

For example, in An Account of Timbuctoo and Housa, Territories in the Interior of Africa, James Grey Jackson reprints a letter he wrote on December 19, 1817 to The Quarterly Journal of Literature, Science, and the Arts, edited at the Royal Institution of Great Britain. In it, he criticizes Adams for inaccurate information about La Mar Zarak or the Red River in the southern confines of the Sahara and the details of the palace of the ruler of Timbuctoo.

The La Mar Zarak of Adams, if any such river exists, may be a corruption of Saga el Humra, i.e. the Red Stream, a river in the southern confines of Sahara, nearly in the same longitude with Timbuctoo. This river the late Emperor of Marocco, Muley Yezzid, announced as the southern boundary of his dominions; but from the accounts which I have had of it, it was not of that magnitude which Adams ascribes to the Mar Zarak, nor was it precisely in the neighbourhood of Timbuctoo, when I was a resident in South Barbary: rivers, however, which pass through sandy or desert districts, often change their courses in the space of twenty-four hours, by the drifting of the moving sands impelled by the wind; instances of which I have myself often witnessed....

The state in which he has represented Timbuctoo, is, I think, extremely inaccurate; and being a slave, it is more than probable, that he was placed in a Fondaque, or Caravansera, belonging to the King, which he mistook for his palace; but that his 
narrative should be deemed inaccurate, because he has described the town of Timbuctoo to be under the sovereignty of a Negro prince, is to me incomprehensible. The various sources of information that I have investigated, uniformly declare that sovereign to be a Negro, and that his name in the year 1800, was Woolo. This account, it appears, is confirmed by Adams, who says, Woolo was King of Timbuctoo in 1810, and that he was then old and grey headed. (435-36) the Adams text can be explained by British Imperial policy. The elaborate edition of the Adams narrative published in London and the interrogation by a "distinguished" group of interrogators hides "an uncommon enthusiasm" in England on the subject of Africa. Africa has called forth two principles of the human mind, "sympathy and curiosity" (163-4). Sparks places British "sympathy" for Africa within the contexts of the Abolitionist movement in Britain arguing that philanthropy and benevolence might end the trade in African and Christian slaves on the coastal regions and in the interior of Africa. But Sparks finds that "curiosity" has defined a new "revival of letters in Europe-the resuscitation of commerce-the formation of political establishments-the new relations" between nations with a new "tide of discovery" and adventurous projects in Britain and Europe (166). Sparks sets the British, and by implication European, "commercial, scientifick [sic], and political" enterprises of mercantilism and colonialism within the African context, calling attention to the "old account of the wealth and magnificence of Timbuctoo and the course and termination of the Niger" (166-7). In contrast, the British have over excited their own curiosity with the desire to "extend their researches into a country, which was known only for its deserts, and the piracies, barbarism, and stupidity of its inhabitants" (166).

Jared Sparks then offers his own close reading of contemporary accounts of Northwest Africa, comparing them to Adams' text. He also uses the testimony of James Grey Jackson whose first-hand account does not square with Adams' narrative. Sparks also makes brief reference to another American shipwrecked sailor, Captain James Riley, and his "recently published" narrative. Furthermore, he quotes a letter from Mr. Storrow of Boston, who examined Adams at Cadiz, stating that Adams "was not the stupid, unthinking, simple being, which we are led to suppose him from the remarks of the London editor" (170).

36 Two issues are intertwined around this question of curiosity and authority: whose evidence, map, experience is to be believed and whose political and social authority can be trusted to edit and record it? Do the editors, Cock and Dupuis, demonstrate disinterested "curiosity" and does their "source" have the geographic, linguistic, historical, and ethnographic knowledge to have his text placed in the record of the African Association, for example? Secondly, Adams' character is central for Sparks: he is a "fabricator" of the "marvellous," "romantick," and fictional (174). Sparks argues that Adams was "disposed" to take advantage of other people's credulity. Thus it was important that Simon Cock and Joseph Dupuis tried to establish Adams' moral probity. Sparks argues that all those men in London, whether explorers, merchants, geographers, scientists, leaders of the Abolitionist movement, or administrators and investors in the African Association, the African Institution, and the Merchant Association Trading with the Interior of Africa made Adams' evidence into an embodiment of their own desire, their own mercantile colonial agendas. ${ }^{8}$ I think we 
can now see that Adams may have taken them in, but they aided and abetted him, especially the members of the Merchant Association Trading with the Interior of Africa.

Sparks ends his review with a report of his search for Adams' family records in Hudson, New York. He can find no written "authority" for Adams' claims of family settlement there, or of a ship named "Charles" sailing from that port in May or June of 1810 (182), when Adams claims he begun his journey. Sparks' desire is to usurp Adams' archival authority by attacking the writer's identity, moral character, and text. To quote Barbara Benedict's generalization about the intellectual history of the period, "curiosity thus denotes both the ambitious penetration of the unknown and the astute penetration of the untrue" (Benedict, 19): curious writers and reviewers challenge curious travellers, adventurers, and explorers. The trick for both archivist and critical reviewer was to balance self-effacement and self-assertion. It is this tension that Nigel Leask discusses so thoroughly in travel writing of the period, showing that there was a difference between the merely "curious" and the "aesthetics of curiosity" (1-54).

Within the construction of the European "orientalist" archive, there was a social boundary defining what could be said, what could be seen, and how the explorer/ traveller might present "evidence" for preservation in the archive (Said 19-22). Such an archive, as other critics have argued, was not always convincing, nor was it available to all cultures or societies, but it was established and maintained through the demarcation of identity and difference within a transatlantic pattern of textual circulation. Also, I have argued that archives can help establish, through the recording of and systematization of language and evidence, a discourse used to interrogate the authority of the archive itself.

39 Finally, Simon Cock positioned the Adams Narrative at a well-chosen historical moment in which the interests of merchants, missionaries, and explorers came together in an attempt to open North West African markets to "civilizing commerce" to counter the effects of piracy and the slave trade in the Maghreb. Two organizations, the English Abolition Society and the English Association for Promoting the Discovery of the Interior Parts of Africa, both shared the discourse of "enlightened capitalism" in which new kinds of raw materials were to be found, traded, and sold in Africa rather than slaves. The "barbaric traffic" in people was to be replaced by a "profitable and enlightened commerce" (Gould 40-42). This argument, which was shared by both abolitionists and scientific explorers, was also connected to a public discourse about honouring existing treaties and establishing clearly articulated trade routes along both the coasts and into the interior of Africa. On both sides of the Atlantic, the roles of the reviewer and explorer were changing and being debated, and within these negotiations new forms of public curiosity were defined.

The research and writing of portions of this paper began at the Vera Harmsworth Library, Oxford University while I was a research fellow at the Rothermere American Institute and I wish to thank their gracious and helpful staff. Colleagues at the University of Tromsø in the Border Aesthetics Research Project have read a version of the paper and I have benefited greatly from their suggestions. In a forthcoming article, I have analysed only American Barbary Coast narratives of the early Nineteenth century as they write race and erase race on their captive body (American Studies in Scandinavia, 43:2, 2012). 


\title{
BIBLIOGRAPHIE
}

\author{
Works Cited
}

Adams, C. H. ed. The Narrative of Robert Adams, A Barbary Captive: A Critical Edition. Cambridge: Cambridge University Press, 2005. Print.

Allison, Robert The Crescent Obscured: The United States and the Muslim World, 1776-1815. New York: Oxford University Press, 1995. Print.

Barrow, John. Riley, An Authentic Narrative of the Loss of the American brig Commerce, wrecked on the Western Coast of Africa, in the month of August, 1815; with an Account of the Sufferings of her surviving Officers and Crew, who were enslaved by the wandering Arabs on the Great African Desert, or Zahahrah $\&$., Quarterly Review, January 1817, 287-321. Print.

- - -. The Narrative of Robert Adams, a Sailor, who was wrecked in the Year 1810, on the Western Coast of Africa, was detained three Years in Slavery by the Arabs of the Great Desert, and resided several Months of that Period in the City of Tombuctoo; with a Map, Notes, and an Appendix, Quarterly Review, January 1816, 453-75. Print.

- - -. Smith, Mémoire sur la Nécessité et les Moyens de faire cesser les Pirateries des Etats Barbaresques. Reçu, considéré, et adopté à Paris en Septembre-à Turin le140ctobre, 1814-à Vienne durant le Congrès; Walter Croker, A Letter to a Member of Parliament on the Slavery of the Christians at Algiers; Narrative of a Ten Years' Residence at Tripoli, in Africa, from the original Correspondence, in the possession of the Family of the late Richard Tully, Esq. the British Consul; comprising authentic Memoirs and Anecdotes of the reigning Bashaw, Sedi Useph, his Family, and various Persons of distinction; an Account of the Domestic Manners of the Moors, Arabs, and Turks, \&c.; Keating, Travels in Europe and Africa; comprising a Journey through France, Spain, and Portugal, to Morocco, with the particular Account of that Empire, \&c.; Macgill, An Account of Tunis, of its Government, Manners, Customs, and Antiquities; especially of its Productions, Manufactures, and Commerce, Quarterly Review, April 1816, 139-83. Print.

Baepler, Paul. "The Barbary Captivity Narrative in American Culture". Early American Literature 39(2) (1995) 217-246. Print.

- - -. White Slaves, Black Masters. Chicago: University of Chicago Press, 1999. Print.

Bhabha, H. K. The Location of Culture. London: Routledge, 1994. Print.

Blum, Hester. "Pirated Tars, Piratical Texts: Barbary Captivity and AmericanSea Narratives"Early American Studies: An Interdisciplinary Journal, (Volume 1, Number 2, Fall 2003): 133-158. Print.

Brezina, J. C. "A Nation in Chains: Barbary Captives and American Identity". Captivating Subjects, Writing Confinement, Citizenship, and Nationhood in the Nineteenth Century. Ed. J. A. W. Haslam and Julia M. Wright. Toronto: University of Toronto Press, 2005.201-219. Print.

Burnham, M. Captivity and Sentiment: Cultural Exchange in American Literature, 1682-1861. Hanover: New Hampshire: University Press of New England, 1997. Print.

Chandler, James. England in 1819. Chicago: University of Chicago Press. 1998. Print.

Chaplin, Joyce E. "Knowing the Ocean, Benjamin Franklin and the Circulation of Atlantic Knowledge" Science and Empire in the Atlantic World.Ed. by James Delbourgo and Nicholas Dew, London: Routledge, 2008. 73-96. Print.

Clissold, Stephen. The Barbary Slaves. London: Paul Elek, 1977. Print. 
Colley, Linda. Captives. New York: Pantheon Books, 2002. Print.

- - - The Ordeal of Elizabeth Marsh, A Woman in World History New York: Anchor Books, 2008. Print.

Curtin, Philip. The Image of Africa: British Ideas and Action 1780-1850. Madison, Wis.: University of Wisconsin Press, 1964. Print.

De Certeau, M. Heterologies: Discourse on the Other. Trans. Brain Massumi. Minneapolis: University of Minnesota Press, 1986. Print.

Derrida, J. Of Grammatology. Trans. Gayatri Chakravorty Spivak. Baltimore: John Hopkins University Press, 1976, corrected edition 1998. Print.

Fabian, Ann. The Unvarnished Truth, Personal Narrative in Nineteenth Century America. Standford: Standford University Press, 2000. Print.

Heffernan, Michael. “A dream as frail as those of ancient Time' : the in-credible geographies of Timbuctoo" Environment and Planning D: Society and Space (19 2001): 203 - 225. Print.

Helmers, M. and Mazzeo, T. "Introduction: Travel and the Body" Journal of NarrativeTheory. 35, 3, (Fall 2005): 267-276. Print.

Jackson J. An Account of the Empire of Morocco, and the Districts of Suse and Tafilelt; Compiled from Miscellaneous Observations made during a Long Residence in, and Various Journeys through, these Countries to which is added an Account of Africa, and an Interesting Account of Timbuctoo, the Great Emporium of Central Africa London: 2nd edition, W Bulmer and Co., 1811. Print.

Jackson J. An account of Timbuctoo and Housa, Territories in the Interior of Africa, by El Hage Abd Salam Shabeeny; with Notes, Critical and Explanatory. To which is added, Letters descriptive of Travels through West and South Barbary, and Across the Mountains of Atlas; also, Fragments, Notes, and Anecdotes; Specimens of Arabic Epistolary Style etc. etc. London: Longman, Hurst, Rees, Orme and Brown, 1820. Print.

Latour, Bruno. Science in Action: How to Follow Scientists and Engineers through Society. Milton Keynes: Open University Press 1987. Print.

Lambert, Frank. The Barbary Wars: American Independence in the Atlantic World. London: Hill and Wang, 2007. Print.

Leask, Nigel. Curiosity and the Aesthetics of Travel Writing 1770-1840. Oxford: Oxford University Press, 2002. Print.

Linebaugh, P. The London Hanged, Crime and Civil Society in the Eighteenth Century. London: Verso, 2006. Print.

Montgromery, B. "White Captives, African Slaves: A Drama of Abolition." Eighteenth-Century Studies 27(4, 1994): 615-630. Print.

Paddock, Judah. Narrative of the shipwreck of the ship Oswego, on the Coast of South Barbary, and of the Sufferings of the Master and the Crew while in Bondage among the Arabs: Interspersed with Numerous Remarks upon the Country and its Inhabitants, and Concerning the Peculiar Perils of that Coast. London: Longman, Hurst, and Rees, 1818. Print.

Park, Mungo. Travels in the Interior Districts of Africa. Durham and London, Duke University Press, Reprint of 1799 edition, 2000. Print.

Pfister, Manfred "Travelling in the Traces of ... Italian Spaces and the Traces of the Other" Sites of Exchange, Europe Crossroads and Fault lines. Ed. Maurizio Ascari and Adriana Corrado. Amsterdam: Rodolpi, 2006. 25-38. Print. 
Riley, James. (1817). An Authentic Narrative of the loss of the American Brig Commerce, wrecked on the western coast of Africa, in the month of August, 1815, with an account of the sufferings of her surviving officers and crew, enslaved by the wandering Arabs on the great African desert, or Zahahrah; and observations historical, geographical, \&c. made during the travels of the author, while a slave to the Arabs, and in the empire of Morocco. London, John Murray based upon the American edition New York: James Riley, 1817. Print.

Riley, James. Sufferings in Africa based upon a mid-nineteenth century edition of Captain's book. New York: Skyhorse Publishing, 2007. (This edition is abridged but easily available. It deletes about one third of the text that focuses on Sidi Hamet's narrative of a journey to Timbuctoo and Riley's chapter condemning the slave trade in America. Print.

Rojas, M. E. “Insults Unpunished': Barbary Captives, American Slaves,

and the Negotiation of Liberty." Early American Studies 38(2,2003): 159-186. Print.

Said, Edward W. Orientalism. New York: Vintage, 1978. Print.

Wilson, Scott. Cultural Materialism, Theory and Practice. Oxford: Blackwell Publishers, 1995. Print.

\section{NOTES}

1. There had been an earlier text of Adams' narrative, which was written down in Africa in 1810 as an "as told to narrative" but not published because of questions about its veracity. It did appear in the United States in an article in the North American Review, "Interior of Africa", May 1817 , edited by Jared Sparks. It will be discussed in the second part of this paper. The text was published first in England, in 1816; in Boston, Paris, and Stockholm in 1817; and in Amsterdam in 1818. It was anthologized in Boston in abbreviated form in $1842,43,46$, and 48 , following the text of 1816. The London text was published by John Murray in a uniform edition with Mungo Park's A Journal of a Mission to the Interior of Africa in the Year 1805 (published in 1815, also by John Murray), with a fold-out map, an elaborate table of contents, chapter headings, and paper and type face as used in Park's book. The text also had the same format and publisher as the publications of the Association for Promoting the Discovery of the Interior Parts of Africa, and of the Records of the African Association. In 2005 the British 1816 edition was published as the Narrative of Robert Adams, A Barbary Captive A Critical Edition edited by Charles Hansford Adams. All internal citations will be to this edition labelled Adams throughout, as will the reviews of Jared Sparks that are included as an appendix.

2. "Even on land, sailors looked different. Their rocking gait, sunburned skin, lash-scarred bodies, outlandish clothing, and eventually tattoos gave them away, and their argot was quite deliberately designed to exclude outsiders" (75) - Joyce E. Chaplin, "Knowing the Ocean, Benjamin Franklin and the Circulation of Atlantic Knowledge." Linda Colley also comments on the appearance of sailors in the period: they were often deeply tanned and wore pigtails and many were mulattos who lived in a world apart, a "generation that differed from all the world" (cited by Colley, 14). They formed their own communities which were usually more equalitarian and which had knowledge of maps, charts, boats and the sea as well as foreign lands. But most important their language was usually a set of pidgin languages or lexical expressions, which deliberately excluded outsiders. See Colley, The Ordeal of Elizabeth Marsh, A Woman in World History. Additionally, she states that "in mid-eighteenth century English the use 'dark' as a description of complexion, like 'black', possessed no necessary racial connotations" (315).

3. Simon Cock (1774? -1837) identifies himself in three or four different ways in his published works: as Secretary of the London Dock Company, or in 1821 as a "London Merchant", or in the 
Adams text as working "in the African Office of the Company of Merchants Trading to Africa". In the Bodleian Catalogue there are 11 pamphlets and texts attributed to S. Cock or Simon Cock. They include testimony before a Parliamentary Committee in which Cock argues for an increase in the number of slaves carried in boats run by commercial slave traders. In another his views can be seen to be representative of Liverpool Merchants who dealt in slaves and other goods in the slave trade triangle. A nineteenth-century biographical dictionary lists Cock working in London and Liverpool, and dying in 1837 in Chiswick. Charles Hansford states in "a critical edition" of the Adams text that Cock gave evidence to Parliamentary Committees investigating the Slave Trade in 1815-1816.

4. Barrow summarizes Adams' narrative of shipwreck, captivity and a journey to Timbuctoo. He then turns his attention to Adams' knowledge of geography and natural history, commenting on his mysterious background and mentioning that the he had been one of the "gentlemen" asked to question Adams. Barrow has reviewed Adams descriptions of Timbuctoo, comparing them with earlier historical accounts, and then states, "no reasonable doubt can be entertained of the general accuracy of Adam's narrative" (Quarterly Review, Jan., 1816, 472). For Barrow, too, the figure of Mungo Park endures in the narrative.

5. The text also makes little reference to the abolition of the slave trade, a commonplace in American Barbary Coast Captivity narratives of the period, but here there are detailed discussions of the African slave trade in both the narrative and in the notes. See for example, James Riley's An Authentic Narrative of the loss of the American Brig Commerce, wrecked on the western coast of Africa, in the month of August, 1815, with an account of the sufferings of her surviving officers and crew, who were enslaved by the wandering Arabs on the great African desert, or Zahahrah; and observations historical, geographical, \&c. made during the travels of the author, while a slave to the Arabs, and in the empire of Morocco (1817), and Judah Paddock's Narrative of the shipwreck of the ship Oswego, on the coast of south Barbary, and of the sufferings of the master and the crew while in bondage among the Arabs; interspersed with numerous remarks upon the country and its inhabitants, and concerning the peculiar perils of that coast (1818). All three texts were published on both sides of the Atlantic within two years of each other; each author claimed to have been born in Hudson, New York, and to have left from that port before being shipwrecked off the Atlantic Coast of Africa.

7. The question of Adams' ethnicity and his position as "slave" was complicated also by the public debate about the actions of the lone explorer in Africa: should he travel incognito, disguising his European identity, language, religion, and scientific equipment, or should he be all kitted out in military uniform or "European dress". This debate was going on in the writings of Jackson, Barrow, members of the African Association, and within the periodicals in which reviews of exploration texts were printed (see Heffernan, 214-216). See Jackson for a contemporary response, which contradicts Heffernan's reading of some of the sources. See Jackson's An Account of Timbuctoo and Housa, Territoriesin the Interior of Africa, 1820, ("Preface" viiiix, 135-6, 266-272).

8. The American press and the American government, during and after the Anglo-American War of 1812-14, supported "free trade" with the Barbary States and all along the Northwest Atlantic Coast of Africa. American historians such as Frank Lambert argue that the War rhetoric created a binary opposition between British mercantile colonialism, coded "piracy" and American free trade (Lambert, 6, 195-198). 


\section{RÉSUMÉS}

This paper discusses the reception of a Barbary Coast Captivity Narrative by Robert Adams, published in 1816. The text has often been mentioned in studies of the Barbary Coast narrative but not as a document of a transatlantic discourse about African exploration, ethnography, and colonial development. The creation of Adams text and the creation of the Adams archive will be the subject of the paper as seen by contemporary sources on both sides of the Atlantic. The creation of the Adams narration in the city of London is played off again in the reception of the Adams narrative in Boston. Each set of textual "editors" and reviewers attempt to use the text to intervene in a debate about Timbuctoo, the future of African exploration, and the ways a literary "curiosity" is placed within the aesthetic and ideological needs of emerging discourses of African exploration and racial representation in the first decades of the $19^{\text {th }}$ century on both sides of the Atlantic.

\section{INDEX}

Keywords : Robert Adams, Barbary Coast Narrative, transatlantic, archive, centres of calculation, travel literature, Jared Sparks, nationalism, narration, Africa, Abolition, Timbuctoo.

\section{AUTEUR}

\section{STEPHEN F. WOLFE}

University of Tromsø 